UDC 81-11

DOI https://doi.org/10.26661/2414-9594-2020-1-1-10

\title{
THE SUBSPHERE "UNIVERSUM" - A CONCEPTUAL FIELD OF THE POLITICAL METAPHOR IN THE UKRAINIAN AND ENGLISH
}

\author{
Kabantseva N. V. \\ Lecturer of the Foreign Language \\ College of Law \\ of the National University "Odessa Law Academy" \\ Biskvitnyi Alley, 3, Odesa, Ukraine \\ orcid.org/0000-0002-5566-407X \\ kanadezhda1@gmail.com
}

Key words: conceptual field, politics, political metaphor, conceptosphere, subsphere, universum.
The article is devoted to the study of the subsphere "Universum" as a conceptual field of political metaphor on the basis of the Ukrainian and English languages. The conceptual fields in the political metaphor on the basis of journalistic discourse of the Ukrainian and English languages are filled with cultural and universal specifics, where the person models a political reality.

The objective spatial reality of the subsphere "Universum" includes metaphors for the designation of objects and characteristics of space and movement, movement in space, perception of color, sound, and scent, is likened to objects and subjects of political processes. The presented subsphere includes and describes the phenomena of political life in images that cover the parameters of the world, they are universal and can characterize both human activity.

The specific features of the subsphere "Universum" as a conceptual field of a political metaphor are its heterogeneity, since it includes and describes the phenomena of political life in images that encompass the parameters of the surrounding world of the human.

The subsphere "Universum" in the Ukrainian and English languages includes the fundamental donor conceptual sphere "Outworld". The phenomena of the external world are included into this sphere, they exist beyond the will of the person, on which he can influence indirectly. Thus, the subsphere "Universum" consists of two conceptual fields: "Space and movement" and "Perception of surrounding reality". The semantic filling of these conceptual fields is divided into frames in both languages of the given research.

The investigation's degree of study and the lingvo-cognitive features of the subsphere "Universum" are discovered. The frequency of using the metaphors in the political discourse of the presented subsphere and connotations' correlation of the subsphere "Universum" is analyzed and the comparative analysis of the obtained results on the material of both languages of the research is given. 


\title{
СУБСФЕРА «УНІВЕРСУМ»- КОНЦЕПТУАЛЬНЕ ПОЛЕ ПОЛІТИЧНОӤ МЕТАФОРИ В УКРАЇНСЬКІЙ ТА АНГЛІЙСЬКІЙ МОВАХ
}

\author{
Кабанцева Н. В. \\ викладач іноземної мови \\ Юридичний фаховий коледж \\ Національного університету «Одеська юридична академія» \\ Бісквітний провулок, 3, Одеса, Україна \\ orcid.org/0000-0002-5566-407X \\ kanadezhda1@gmail.com
}

Ключові слова: концептуальне поле, політика, політична метафора, кониептосфера, субсфера, універсум.
Статтю присвячено дослідженню політичної метафори субсфери «Універсум» як концептуального поля складової частини донорської сфери «Навколишній світ» на базі української та англійської мов. Концептуальні поля політичній метафорі на основі публіцистичного дискурсу української та англійської мов наповнені культурною та загальнолюдською специфікою. Людина моделює політичну реальність, проводячи аналогію зі світом живої та неживої природи.

Об’єктивна просторова реальність субсфери «Універсум» включає метафори для позначення об'єктів та характеристик простору та руху, руху в просторі, сприйняття кольору, звуку та запаху, уподібнюючи об'єктивну просторову реальність об'єктам та суб'єктам політичних процесів. Представлена субсфера включає і описує явища політичного життя в образах, які є універсальними і можуть характеризуватись як діяльність людини. До особливостей субсфери «Універсум» як складової частини понятійного поля політичної метафори належить іiі неоднорідність, оскільки вона включає та описує явища політичного життя та діяльності в образах, що охоплюють параметри навколишнього світу.

Субсфера «Універсум» є складовою частиною фундаментальної донорської понятійної сфери «Навколишній світ» на матеріалі української та англійської мов. У склад цієї субсфери входять явища зовнішнього світу, вони існують поза волею людини, на які вона може впливати опосередковано. Отже, субсфера «Універсум» складається із двох концептуальних полів: «Простір та рух» та «Сприймання навколишньої дійсності». Семантичне наповнення цих концептуальних полів поділено на фрейми в обох мовах дослідження.

У статі представлений лінгво-когнітивні особливості політичної метафори субсфери «Універсум». Проаналізована частотність використання політичної метафори цієї субсфери на матеріалі обох мов дослідження, співвіднесено конотативне забарвлення субсфери «Універсум» та проведено порівняльний аналіз отриманих статистичних даних на матеріалі української та англійської мов.
Political metaphors are one of the most important components of journalistic discourse. Conceptual fields of political metaphors in journalistic disourse in the Ukrainian and English are filled with the content of national linguistic consciousness, and therefore they are presented as semantic formations marked by linguistic and cultural specifics. Conceptual fields of political metaphors attract the attention of many domestic and foreign researchers, on whose work we rely in the given study $[1 ; 2 ; 3 ; 4 ; 5 ; 6 ; 7]$.
However, the conceptual fields' comparative study of modern political metaphor of the subsphere "Universum" of the fundamental donor conceptual sphere "Outworld" on the basis of the Ukrainian and English languages is not investigated, which is the actuality of the study.

The purpose of the work is a comparative study of the subsphere "Universum"'s political metaphors as a component of the donor conceptual sphere "Outworld" on the basis of the Ukrainian and English languages. 
The object of the research is the subsphere "Universum" as a component of the donor conceptual sphere "Outworld" of Ukrainian and English.

The subject of the research is the political metaphors of the subsphere "Universum" on the basis of the Ukrainian and English languages.

The subsphere "Universum" contains political metaphors to denote objects and characteristics of space and movement, movement in space, perception of color and scent, assimilating objective spatial reality to objects and subjects of political processes.

Thus, the subsphere "Universum" consists of two conceptual fiends: "Space and movement" and "Perception of suppounding reality" (see figure 1).

According to Scheme 1, the conceptual field «Space and movement» occupies the first place in frequency among the conceptual fields of the subsphere "Universum" in both Ukrainian and English (see Scheme 1). The given conceptual field is verbalized through the semantic field, which consists of lexical units, expresing movements in space, types of space, universal spatial nominations, which are inherent in different types of space, for example:

(1) Trump: We're getting 'closer and closer' on tax bill. - There is a use of the metaphor "getting "closer and closer" "in sentence (1) The metaphorical meaning is based on a direct dictionary interpretation of the token "close" - "only a short distance away or apart in space or time" [9]. In a metaphorical sense, the phrase "getting "closer and closer" means progress in the consideration of the tax bill, which will eventually allow Congress to agree on it and vote in favor. The metaphor of "getting closer and closer" has a positive connotation, which is modeled semantically and contextually.

The semantic content of the conceptual field "Space and movement» is divided it into two frames: "Moving in space" and "Types of space" (see figure 2).

According to the results of Scheme 2, it is established that in the Ukrainian language the frame "Types of space" occupies the first place and makes 35\% of the total political metaphors of the conceptual field "Space and movement" (see Scheme 2) unlike in English, where the political metaphors of this frame are less frequent (23\%) (see Scheme 2). The presented frame includes metaphors depicting the nominations of various metaphorically reinterpreted images of celestial and airspace, for example:

(2) Political Galaxy Makes for Easy Voting. - The metaphor "political galaxy» is used in example (2). The metaphorical meaning is based on the direct vocabulary meaning of the token "galaxy - "a system of millions or billions of stars, together with gas and dust, held together by gravitational attraction" [9]. It's about a special computer program called Political Galaxy, which allows users to enter the name of politicians, and instantly get information about serious problems associated with their political campaign, thus giving the voter the opportunity to study the biography, voting, positions, ratings, speeches and funding of each of the candidates for each issue. The metaphor has positive connotation, which is related to the content of the article.

The second place among the frames of the conceptual field "Space and movement" in the Ukrainian language belongs to the frame "Moving in space" $(15 \%)$ in contrast to English, where this frame ranks first in frequency among the frames of the conceptual field "Space and movement" (27\%) (see Scheme 2). This frame displays metaphors denoting the methods and intensity of movement in space, the direction and nature of movement, for example:

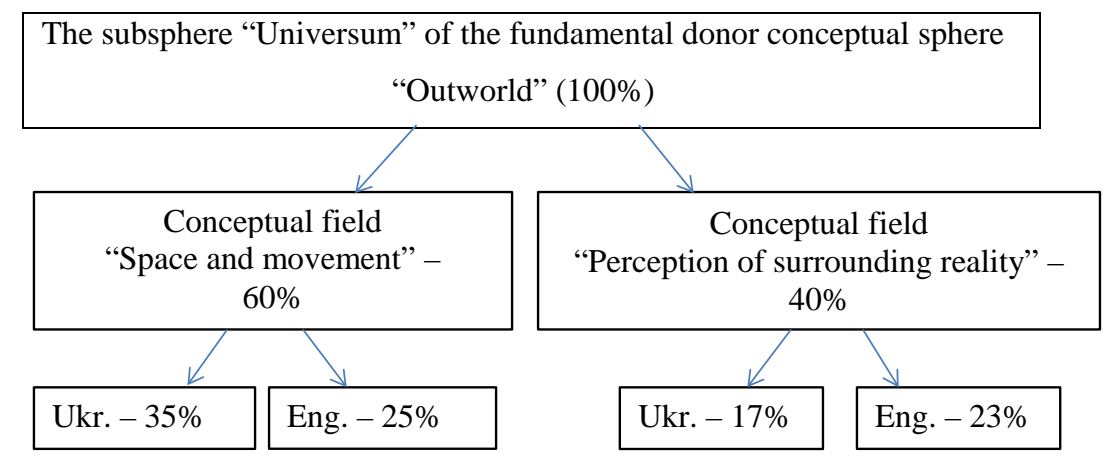

Figure 1. The use frequency of subsphere's conceptual fields "Universum" in Ukrainian and English

Conceptual field “Space and movement” (100 \%)

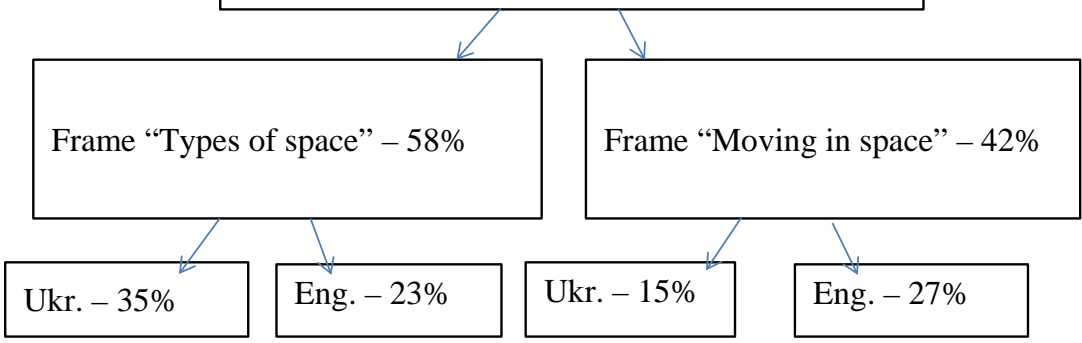

Figure 2. Frame conceptual field's structure "Space and movement" of subsphere "Universum" 
(3) Economy drags Putin's ambitions down to earth. - There is a use of the metaphor drags ambitions down to earth in example (3). The metaphorical meaning of the phrase is modeled by a direct dictionary interpretation of "drag" - "pull (someone or something) along forcefully, roughly, or with difficulty" [9]. This metaphor indicates that the economic situation in the country returns Russian President Putin to a reality in which his geopolitical ambitions collide with the realities of the economy and globalization. Metaphor conveys a negative meaning. Such connotations are modeled semantically.

The conceptual field of "Perception of surrounding reality" occupies the second place in frequency among the conceptual fields of the subsphere "Universum" in both languages of the research (see Scheme 1). This conceptual field is verbalized through the semantic field, which in general consists of lexical units that describe political reality in terms based on the perception of color, sound and scent. The conceptual field "Perception of surrounding reality" includes language tools to indicate the color, sound characteristics of space, the scent of the characteristics of space.

The semantic content of the conceptual field "Perception of surrounding reality" is divided it into three frames: "Color", "Sound" and "Scent" (see figure 3).

According to Scheme 3, the frame "Color" is the most frequent in both languages of the study: $25 \%$ in Ukrainian and 15\% in English of the total number of political metaphors of the conceptual field "Perception

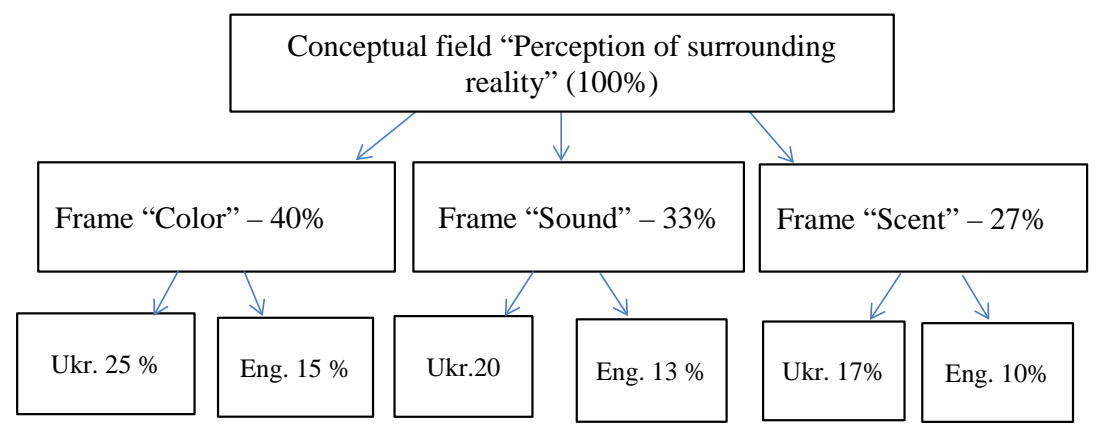

Figure 3. Frame conceptual field's structure "Perception of surrounding reality" of the subsphere "Universum"

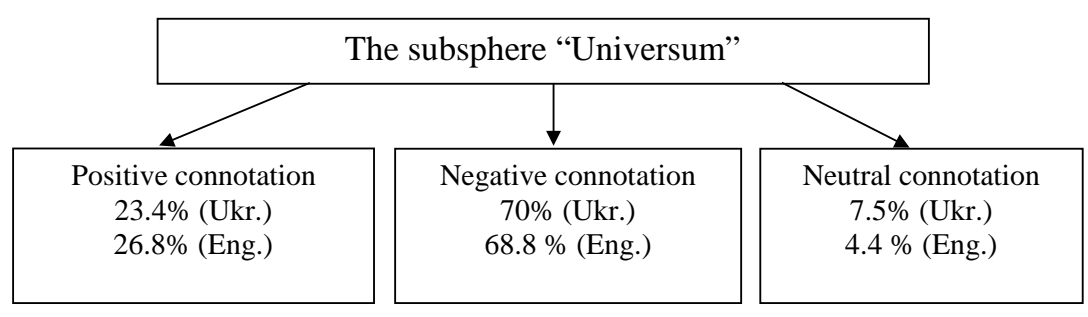

Figure 4. Percentage connotations' correlation of the subsphere "Universum" of surrounding reality". This frame reflects a person's perception of color, which is transferred to the sphere of political life, for example:

(4) Donald Trump is not racist because "green" is only color he sees, Eric Trump says as he defends his father on Fox News. - The metaphor "green he sees" is used in Example (4). The meaning of this metaphor is modeled by a metaphorical dictionary interpretation of the token "green" - "money" [9]. This token meaning is neutrally connoted. In the context of this sentence, it is said that, according to his son, Donald Trump is not a racist, because he sees only the color of money. The neutral connotation is based on the attitude of the recipient to the specified policy, the USA in general and their national currency in particular.

According to the results of the study, the second most frequent frame is «Sound» in Ukrainian (20\%) and in English (13\%) of the total political metaphors of the conceptual field "Perception of surrounding reality" (see Scheme 3). This frame reflects a person's perception of sounds, the image of which is transferred to the sphere of political life, for example:

(5) Parliament ends on high note. - In example (5) we observe the use of the metaphor "ends on high note", the meaning of which is based on a metaphorical dictionary interpretation of the phrase "high note - a successful point in an event or period of time" [9]. In the context of the sentence, it is said that the parliamentary session ended with the announcement that the government will provide a bus for schoolchildren in Mangai, which corresponds to the festive Christmas and New Year mood. Therefore, this positive statement became a kind of gift to the city community. The metaphor has a positive connotation, which is modeled semantically and contextually.

The last and least frequent position is occupied by the frame "Scent" in both languages of the conceptual field "Perception of surrounding reality", namely in Ukrainian - 17\% and in English $10 \%$ (see Scheme 3). This frame includes metaphors that name unpleasant and pleasant aromas and scents, for example:

(6) The stench of failure is the one and only thing Trump cannot withstand. - The metaphor "the stench of failure" is used in the example (6). The metaphorical meaning of the metaphor is based on the direct vocabulary meaning of the token "stench" - "a strong and very unpleasant smell" [9]. The metaphor "the stench of failure" has a negative 
connotation, which carries the semantics of the token "stench" - "stench". In the context of this sentence, we are talking about the feeling of imminent failure, which Trump is so afraid of, and therefore forbids disloyal media to truthfully cover the information.

According to the obtained study's results, political metaphors of the subsphere "Universum" are widely used in describing political processes, where the metaphors of the frame "Types of space" occupy the first place in the Ukrainian language $(35 \%)$, while the political metaphors of this frame are less frequent in the English language (23\%). In English, the first place is occupied by the frame "Moving in space" $-27 \%$, in contrast to Ukrainian, where this frame occupies the second place in frequency $-15 \%$. Among the political metaphors of the conceptual field "Perception of surrounding reality" in both study's languages, the first place is occupied by the frame "Color" (25\% Ukrainian and $15 \%$ English). The second place is occupied by the frame "Sound" (20\% in Ukrainian and 13\% in
English). The last place is occupied by the frame "Scent" (17\% in Ukrainian and 10\% in English) in both study's languages.

According to the results of the study, the prevailing majority (70\% in Ukrainian and $68.8 \%$ in English) of political metaphors within the subsphere "Universum" conveys a negative meaning. Positively connoted political metaphors occupy the second place $(23.4 \%$ in Ukrainian and 26.8\% in English). Neutrally connoted political metaphors occupy the last place $(7.5 \%$ Ukrainian and 4.4\% English) (see figure 4):

Thus, the political metaphors of the subsphere "Universum" take an integral part of journalistic discourse, characterizing political life, processes and actions in the life of the country. In the perspective of the study, we are going to compare lingvo-cognitive features of the subsphere "Sacral world" s political metaphors with other conceptual fields of the fundamental donor conceptual sphere "Outworld" and to consider connotative features on the basis of the Ukrainian and English languages.

\section{BIBLIOGRAPHY}

1. Дацишин Х.П. Метафора в українському політичному дискурсі: автореф. дис. на здобуття наук. ступеня канд. філол. наук : 10.01.08. Львів, 2005. 18 с.

2. Жулавська О.О. Актуалізація концепту ТЕРОРИЗМ у сучасному британському газетному дискурсі : автореф. дис на здобуття наук. ступеня канд. філол. наук: 10.01.08. Харків, 2011. 20 с.

3. Чадюк О.М. Метафора у сфері сучасної української політичної комунікації : дис. на здобуття наук. ступ. канд. філол. наук : 10.02.01. Київ, 2005. 230 с.

4. Bratož S. Metaphors in Political Discourse from a Cross-Cultural Perspective. IJEMS. Volume 7, 2014. № 1. P. 3-23.

5. Cienki A. The Application of Conceptual Metaphor Theory to Political Discourse: Methodological Questions and Some Possibile Solutions. In Political Language and Metaphor, edited by T. Carver and J. Pikalo, New York : Routledge. 2008. P. 241-56.

6. Figar V. Analysis of Conceptual Metaphors in the Political Discourse of Daily Newspapers: Structure, Function, and Emotional Appeal (MA Thesis). University of Nis, Faculty of Philosophy, English Department. 2013. 160 p.

7. Musolff A. Metaphor scenarios in public discourse. Metaphor and Symbol, 2006. 21(1). P. 23-38.

8. English Oxford Living Dictionaries. URL : https://en.oxforddictionaries.com (дата звернення: 18.03.2016).

\section{REFERENCES}

1. Datsyshyn Kh. P. (2005) Metafora v ukrainskomu politychnomu dyskursi [Metaphor in the Ukrainian political discourse]: avtoref. dys. na zdobuttia nauk. stupenia kand. filol. nauk : 10.01.08. Lviv, 2005. 18 p. [in Ukrainian].

2. Zhulavska O.O. (2011) Aktualizatsiia kontseptu TERORYZM u suchasnomu brytanskomu hazetnomu dyskursi [Actualization of concept TERRORISM in contemporary British newspaper discourse]: avtoref. dys na zdobuttia nauk. stupenia kand. filol. nauk: 10.01.08. Kharkiv, 2011. 20 p. [in Ukrainian].

3. Chadiuk O. M. (2005) Metafora u sferi suchasnoi ukrainskoi politychnoi komunikatsii [A metaphor in sphere of modern Ukrainian political communication]: dys. na zdobuttia nauk. stup. kand. filol. nauk : 10.02.01. Kyiv, 2005. 230 p. [in Ukrainian].

4. Bratož S. Metaphors in Political Discourse from a Cross-Cultural Perspective. IJEMS. Volume 7, 2014. № 1. P. 3-23.

5. Cienki A. The Application of Conceptual Metaphor Theory to Political Discourse: Methodological Questions and Some Possibile Solutions. In Political Language and Metaphor, edited by T. Carver and J. Pikalo, New York: Routledge. 2008. P. 241-56.

6. Figar V. Analysis of Conceptual Metaphors in the Political Discourse of Daily Newspapers: Structure, Function, and Emotional Appeal (MA Thesis). University of Nis, Faculty of Philosophy, English Department. 2013. 160 p.

7. Musolff A. Metaphor scenarios in public discourse. Metaphor and Symbol, 2006. 21(1). P. 23-38.

8. English Oxford Living Dictionaries. URL: https://en.oxforddictionaries.com (date of application: 18.03.2016). 